\title{
Ectopic Expression of Bioactive Peptides and Serotonin in the Sacciform Gland Cells of Teleost Skin*
}

\author{
S. Fasulo ${ }^{1}$, G. Tagliafierro ${ }^{2}$, A. Contini ${ }^{1}$, L. Ainis $^{1}$, M. B. Ricca ${ }^{1}$, N. Yanaihara ${ }^{3}$ and \\ G. ZACCONE
}

Department of Animal Biology and Marine Ecology ${ }^{1}$, University of Messina, Messina, Italy; Institute of Comparative Anatomy ${ }^{2}$, University of Genoa, Genoa, Italy; and Laboratory of Bioorganic Chemistry ${ }^{3}$, Shizuoka University School of Pharmaceutical Science, Shizuoka, Japan

Received August 6, 1992

\begin{abstract}
Summary. Immunohistochemical methods identified serotonin, and the peptides bombesin and caerulein, in the skin of the teleosts Lepadogaster candollei and Mastacembelus erytrotaenia. In both species, the secretory content of epidermal sacciform cells reacted positively for all three substances. These results are compared with studies on the skin glands of amphibians, which also contain multiple active compounds, and on various neuroendocrine cells of fish. The precise functions of the secretions are not known.
\end{abstract}

Neuropeptides discovered in the brain have close counterparts in other tissues, predominantly in neurons and paraneurons, as well as ectopically in certain sites such as amphibian skin glands (FUJITA et al., 1988; FuJiTA, 1989). The production of peptide/ amine messengers has been recognized immunohistochemically, in some cells which can be regarded as significantly different in nature from the endocrine paraneurons. These include the atrial muscle cells producing atrial natriuretic peptides, the murine salivary glands - especially their ducts - producing nerve growth factor (NGF), epidermal growth factor (EGF), and many bioactive peptides such as caerulein, bombesin and sauvagine (reviews by ERSPAMER, 1983 and RENDA et al., 1989).

Immunohistochemical studies from our laboratory have demonstrated the presence of serotonin (5hydroxytryptamine) and peptides in the endocrine paraneurons of fish epithelia, such as the cutaneous Merkel cells and the neuroendocrine cells of the gill and lung (ZACCONE, 1986; ZACCONE et al., 1989a, b, c, 1991, 1992a, b). The results have also revealed the occurrence of ectopic amine/peptide-producing secretory units in fish skin, i.e. the sacciform and club cells (ZACCONE et al., 1986, 1987, 1988, 1990); these are unicellular glands with a serous secretion that can be distinguished by the basal or central position of their nucleus, among other characteristics (WHITEAR, 1986). The two species of the present investigation do not possess club cells, but have epidermal sacciform cells.

Bombesin and caerulein were first identified in amphibian skin glands of Bombina bombina and Hyla caerulea, respectively; they also occur in the skin of many other amphibians (see ERSPAMER, 1983; ERSPAMER et al., 1984, 1986; YosHIE et al., 1985; SEKI et al., 1989). Caerulein is the third member of the gastrin/CCK family, isolated by ANASTASI et al. (1968a, b). Immunocytochemistry was here used to locate serotonin, bombesin and caerulein in the sacciform cells of two teleost species, Lepadogaster candollei and Mastacembelus erytrotaenia.

\section{MATERIALS AND METHODS}

\section{Tissue and tissue preparation}

The species used were the marine clingfish Lepadogaster candollei (Gobiesocidae), and the Indian freshwater Mastacembelus erytrotaenia (Mastacembelidae). All fish were anaesthetized with tricaine methanesulfonate (MS 222) diluted $1: 1000$. Samples of skin were removed from the dorsal and lateral body wall and fixed with $4 \%$ paraformaldehyde buffered to $\mathrm{pH} 7.2$ with $0.05 \mathrm{M}$ phosphate buffer for $24 \mathrm{~h}$ at $4^{\circ} \mathrm{C}$, rinsed in $0.1 \mathrm{M}$ phosphate buffer for more than $24 \mathrm{~h}$ at $4^{\circ} \mathrm{C}$,

${ }^{*}$ This research was supported by Grants $40 \%$ and $60 \%$ M.U.R.S.T., Rome. 
dehydrated in a graded series of ethanols, embedded in paraplast, sectioned and stained with hematoxylin/eosin and trichrome staining for light microscopic observations.

\section{Immunohistochemistry}

Antisera:

Anti-serotonin antibody (dilute $1: 500$ ) was supplied by Incstar, Stillwater, MN.

The antiserum to amphibian bombesin was purchased from Cambridge Research Biochemical Ltd., England, and diluted $1: 200$. Incubations were made with antisera diluted in phosphate-buffered saline (PBS).

Dr. T. SEKI (Department of Anatomy, Juntendo University School of Medicine, Tokyo) graciously donated the antiserum to caerulein, anti-CCK 10 serum ( $R$ 5911) raised against porcine cholecystokinin-33 amino terminal-specific radioimmunoassay (for preparatory procedure see IGUCHI et al., 1983; SEKI et al., 1989). The antiserum was diluted 1: 4000.

\section{Procedures}

Following deparaffinizing, $5 \mu \mathrm{m}$ sections were rehydrated, equilibrated with $0.1 \mathrm{M}$ PBS $(\mathrm{pH}$ 7.4) and processed for the peroxidase-antiperoxidase (PAP) method (STERNBERGER, 1979) and for the indirect fluorescence technique by Coons et al. (1955).

Peroxidase activity was detected using diaminobenzidine $30 \mathrm{mg} / 100 \mathrm{ml}$ and $\mathrm{H}_{2} \mathrm{O}_{2}(0.01 \%)$ in PBS for $5 \mathrm{~min}$. The specificity of the antisera was established by absorption overnight at $4^{\circ} \mathrm{C}$ with different quantities (10-50 $\mu \mathrm{g} / \mathrm{ml}$ of diluted antiserum) of their respective antigens.

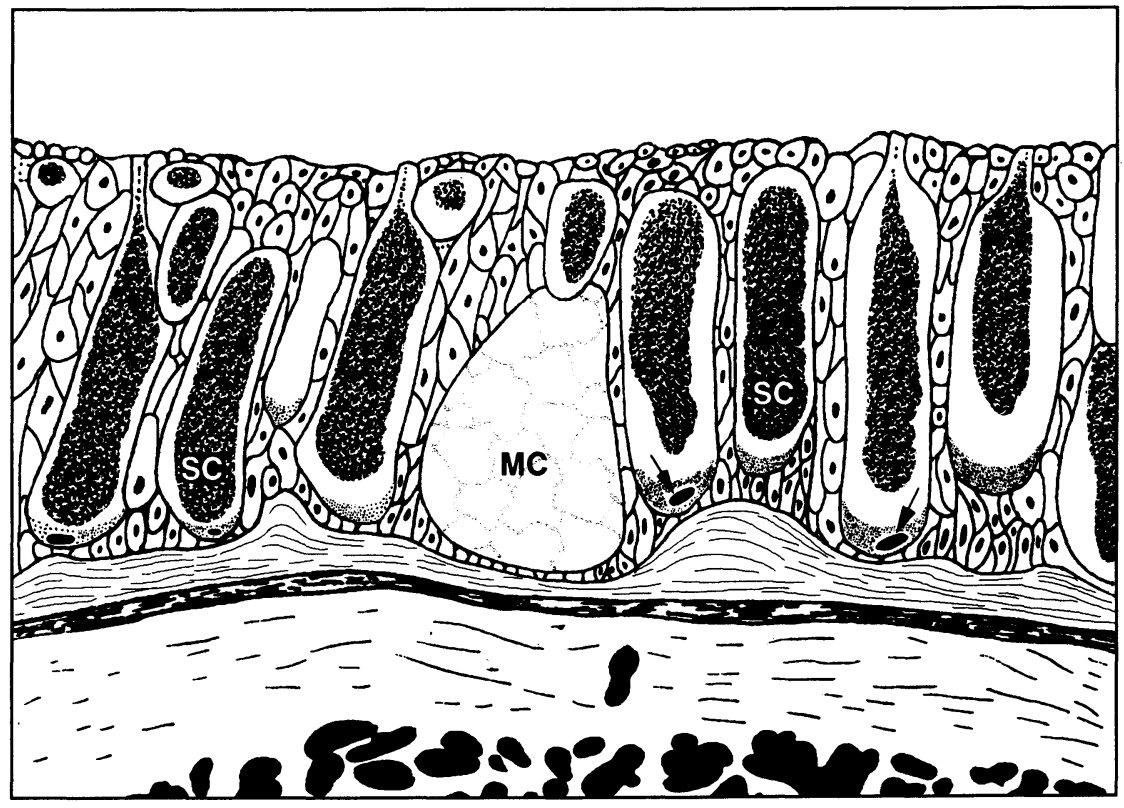

Fig. 1. Schematic representation of the epidermis of Lepadogaster candollei in a transverse section stained with hematoxylin/eosin, shows the presence of sacciform cells $(S C)$ with their dotted cytoplasm and basal nucleus (arrowed). $M C$ mucous goblet cell.

Fig. 2. Hematoxylin-eosin stained skin of Lepadogaster candollei. The epidermis consists of a multilayered epithelium composed of two major cell types, i.e. the sacciform cells $(S C)$ and the large mucous cells $(M C)$. $\times 230$

Figs. 3. and 4. Demonstration of serotonin in the skin of $L$. candollei. Fig. 3. The secretion of some sacciform cells $(S C)$ is labelled with the PAP method. $\times 230$. Fig. 4. Luminal secretion in the sacciform cells $(S C)$ giving a strongly FITC staining. MC large mucous cell. $\times 230$

Fig. 5. Bombesin immunoreactivity in the sacciform cell secretions from the middle layer of the epidermis. The immunoreaction is also seen in the region near the surface of some sacciform cells (SC) of the outer cell layer. Large mucous cells $(M C)$ are immunonegative. $\times 230$

Figs. 6 and 7. Immunohistochemistry of caerulein from the skin of $L$. candollei. Fig. 6. The anti-CCK 10 serum labels the luminal secretions of some sacciform cells $(S C)$ with the PAP method. $\times 230$. Fig. 7 . Sacciform cells $(S C)$ with luminal secretion heavily labelled with the FITC method. $M C$ large mucous cells. $\times 230$ 


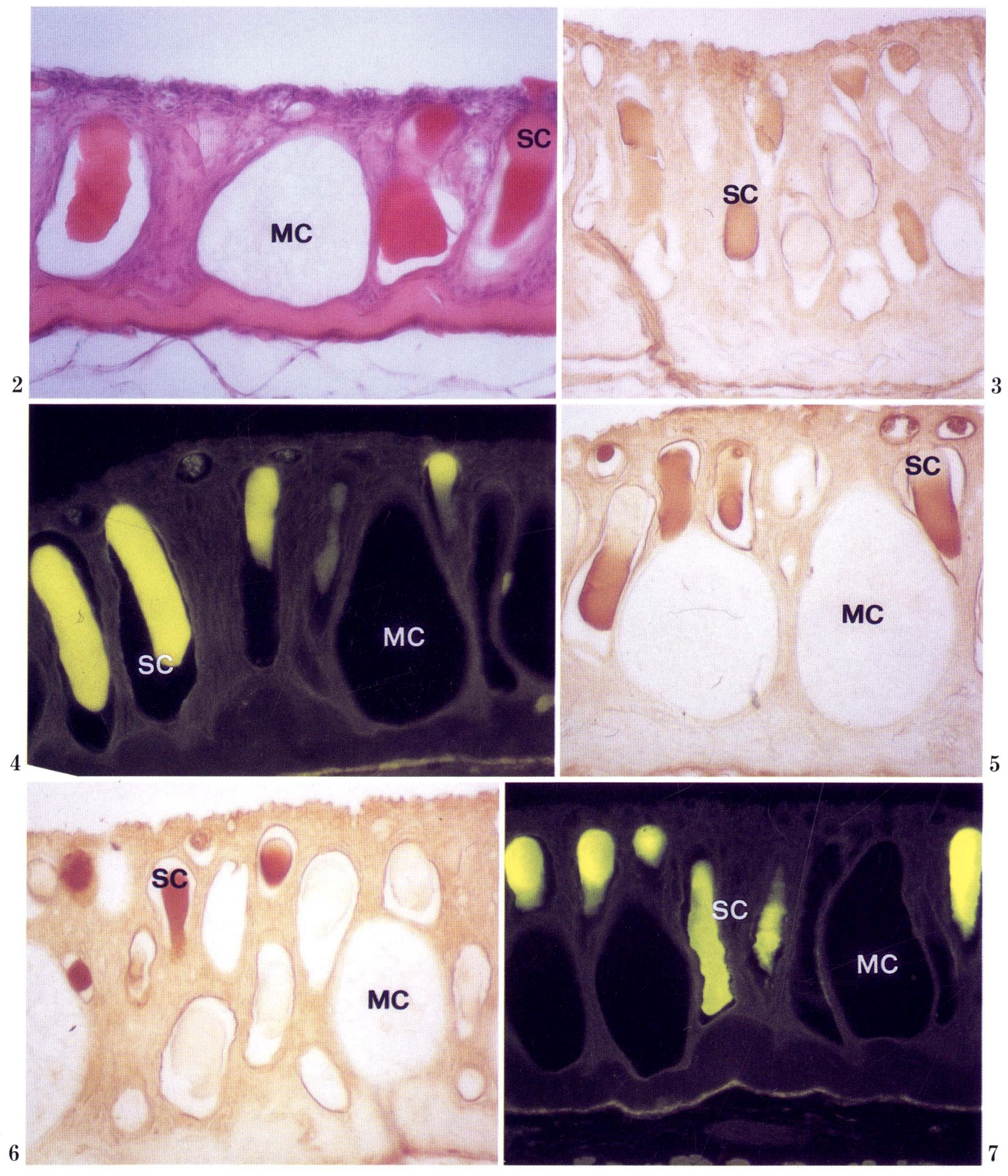

Figs. 2-7. Legends on the opposite page. 
Briefly, immunoreactivity was detected by successive incubation in:

1) specific antiserum at the working dilutions reported above, for $24 \mathrm{~h}$ in a moist chamber at room temperature;

2) either anti-rabbit IGC $(\mathrm{H}+\mathrm{L})$ peroxidase (Chemical Credential ICN, Immunobiologicals, England) $1: 100$ for $1 \mathrm{~h}$ or goat anti-rabbit gammaglobulin conjugated with fluorescein isothiocyanate (FITC, Dakopatts, Denmark) $1: 100$ for $1 \mathrm{~h}$ in a moist chamber at room temperature.

Blocking studies were carried out by preabsorbing the anti-CCK 10 serum with $20 \mu \mathrm{g} / \mathrm{ml}$ of caerulein (Calbiochem). Adjacent sections were processed for immunohistochemistry using preabsorbed and nonpreabsorbed antisera.

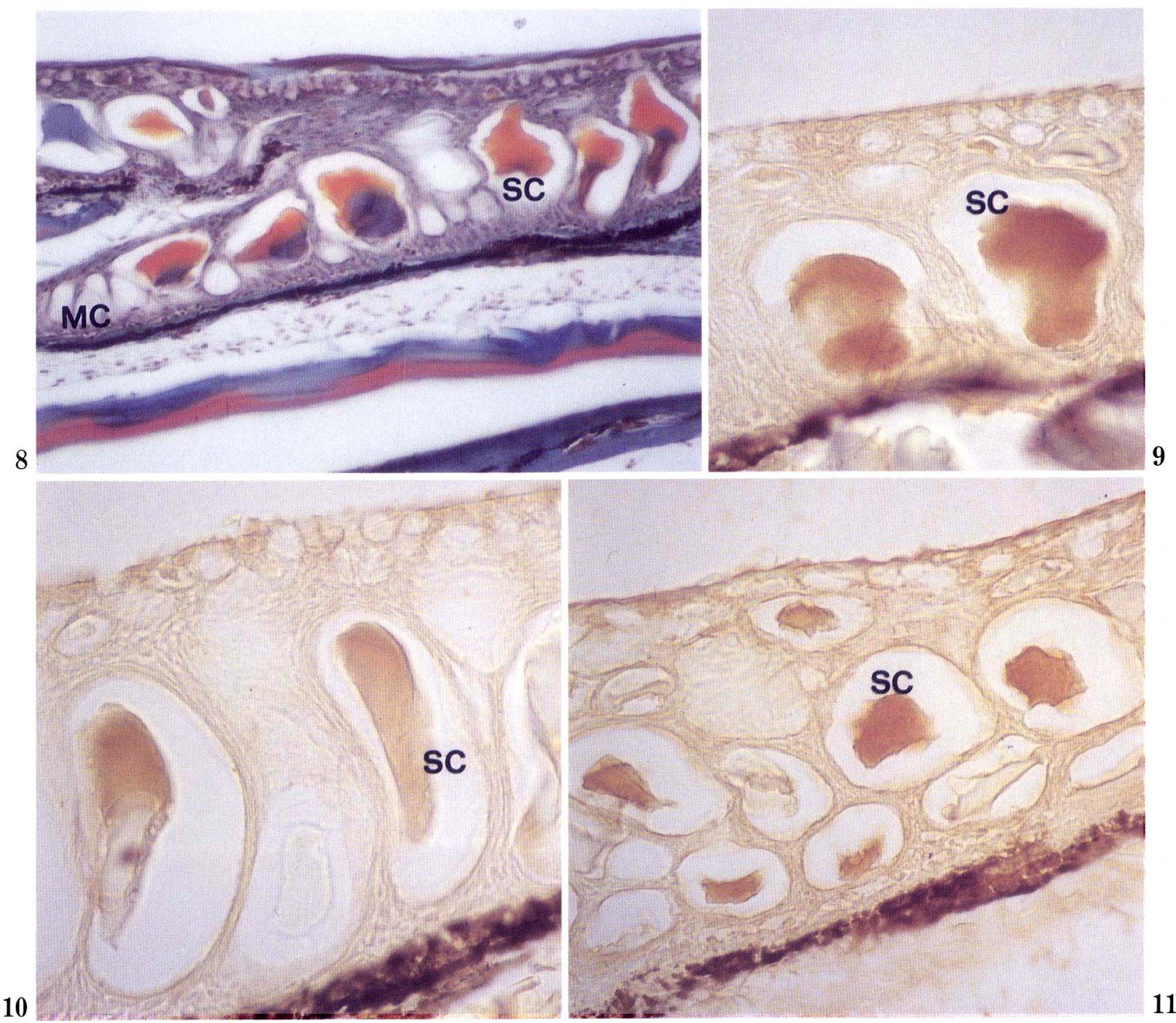

Fig. 8. Trichrome stained skin of Mastacembelus erytrotaenia. Its structural morphology is identical to that observed in the skin of $L$. candollei, having a large proportion of sacciform cells (SC) with regard to mucous goblet cells $(M C) . \times 230$

Fig. 9. Two sacciform cells $(S C)$ in the epidermis of $M$. erytrotaenia stained with serotonin antibody. $\times 460$

Figs. 10 and 11. Varying degrees of positive immunoreaction for bombesin (Fig. 10) and caerulein (Fig. 11) in the luminal secretion of sacciform cells $(S C)$ in the epidermis of $M$. erytrotaenia $\times 460$ 


\section{RESULTS}

The structure of the epidermis of the species studied was described by ZACCONE (1981a, b, 1982a, b) and is shown in Figures 2 and 8. A diagrammatic representation of the epidermis of Lepadogaster candollei is also shown (Fig. 1). In both species there is a multi- layered epidermis containing numerous secretory cells of the sacciform type. These possess a compressed basal nucleus as schematically illustrated, an extremely tenuous peripheral cytoplasm, and a large lumen containing the secretory product, which usually appears shrunken in histological material. In Lepadogaster candollei the sacciform cells are interspersed with mucous goblet cells of comparable large $\mathbf{a}$
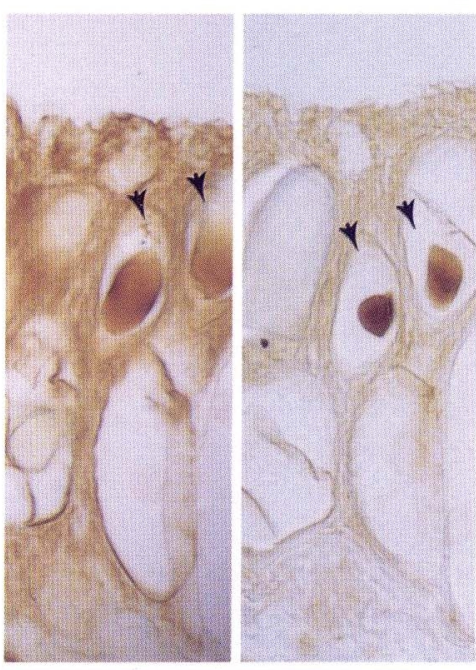

c
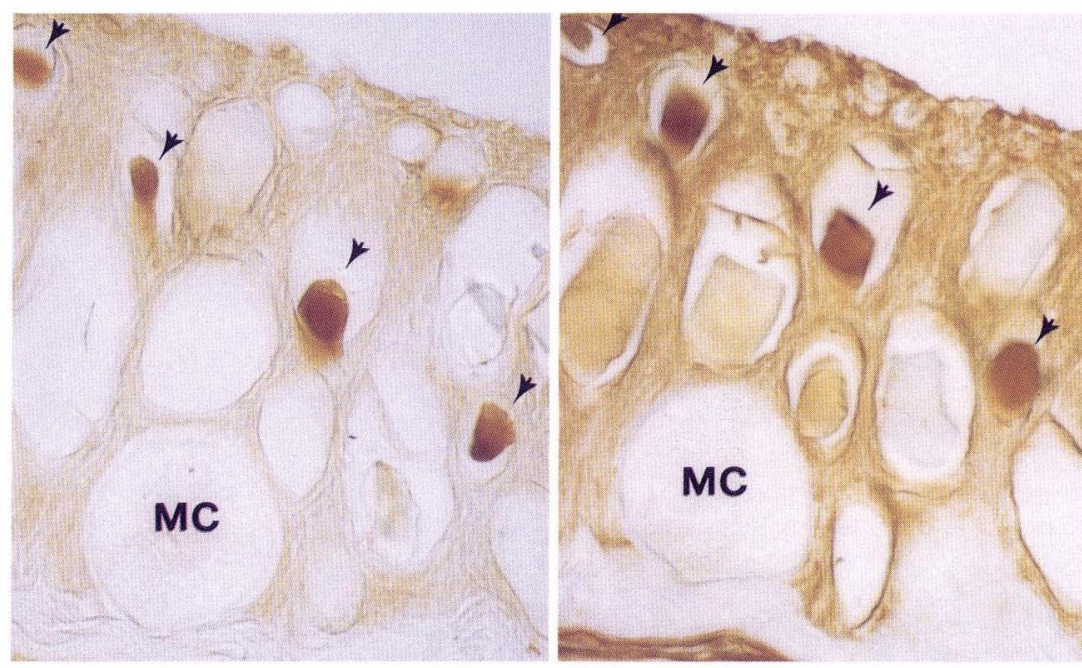
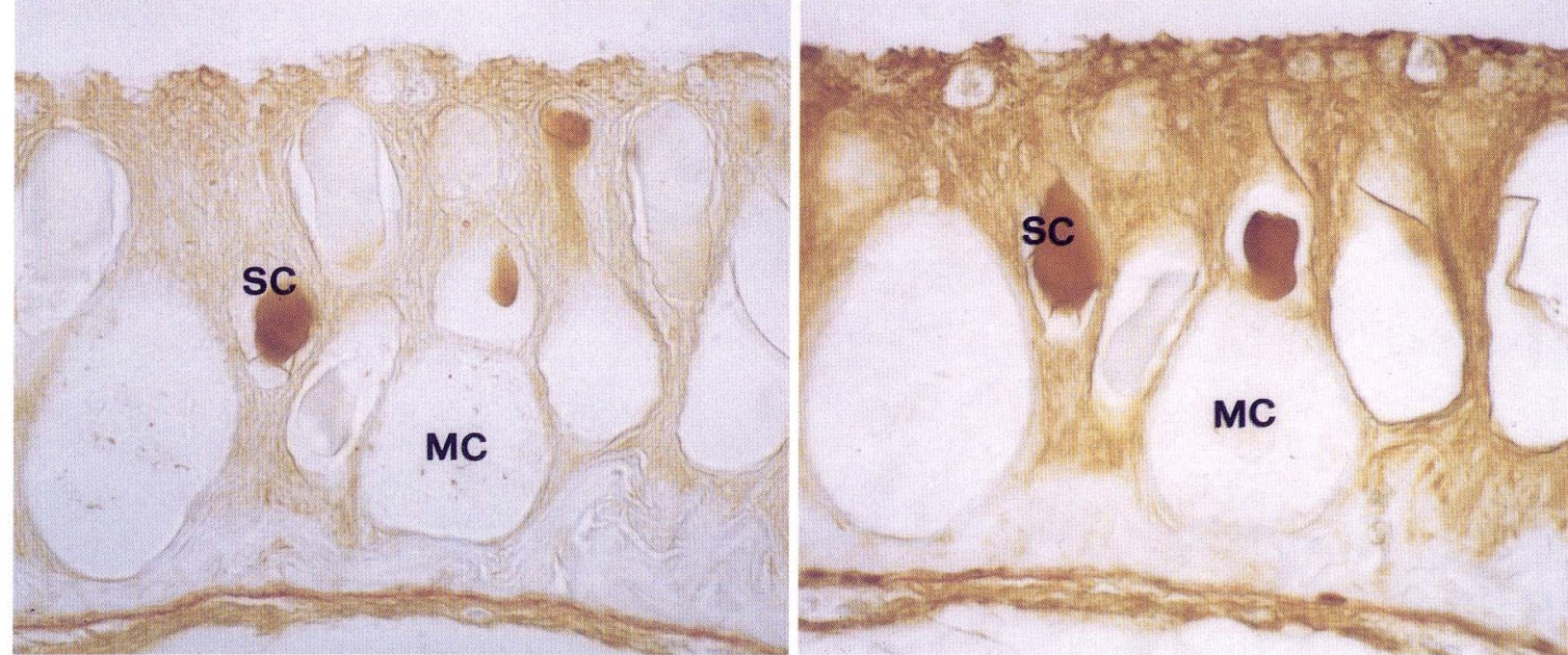

a

Fig. 12 a-d. Adjacent sections of L. candollei epidermis alternatively stained by anti-serotonin, anti-CCK 10 and anti-bombesin sera. a. 5-HT immunoreactivity in the sacciform cell contents (arrowed). b. Caerulein immunoreactivity in the sacciform cell contents. c. Bombesin immunoreactivity. d. 5 -HT immunoreactivity. $M C$ mucous goblet cell. $\times 210$

Fig. 13 a and b. Serial sections of $L$. candollei epidermis showing sacciform cell (SC) secretions labeled with CCK 10 and bombesin antisera. a. CCK 10 immunoreactivity. b. Bombesin immunoreactivity. MC mucous goblet cell. $\times 210$ 
size (Fig. 2). In Mastacembelus erytrotaenia the mucous goblet cells are smaller and confined to the outer layers of the epidermis.

Previous reports (ZACCONE et al., 1986, 1987) had shown the presence of serotonin and bombesin-like substances in the sacciform cells of Lepadogaster candollei, by the PAP method. Figure 3 shows a similar result for serotonin, and Figure 4 demonstrates serotonin by immunofluorescence. Figure 5 shows staining by the PAP method for bombesin; the section cuts the necks of some sacciform cells containing secretion near the skin surface, but there does not appear to be a reaction in the superficial epithelial cells. Figures 6 and 7 show reactions for caerulein by PAP and immunofluorescence methods. In all cases, the large mucous cells have a negative reaction. With the PAP method, not all sacciform cells are equally responsive, the fluorescence technique giving more consistent results.

Figures 9, 10 and 11 show varying degrees of positive reaction to the PAP method for serotonin, bombesin and caerulein, in the sacciform cells of Mastacembelus erytrotaenia. The smaller, more superficial mucous cells react negatively. Figures $12 a-d$ are adjacent sections of $L$. candollei epidermis alternatively stained by anti-serotonin, anti-CCK 10 and anti-bombesin sera. Figures $13 \mathrm{a}, \mathrm{b}$ are serial sections of the same epidermis stained by anti-CCK 10 and anti-bombesin sera.

As can be seen in the figures, the positive reaction is located in the shrunken secretory product of the sacciform cells. Sections from regions adjacent to those with demonstrable immunostaining of the three antisera were used to assess the specificity of the staining. In all instances, a complete loss of immunoreactivity was noted after the control procedures.

\section{DISCUSSION}

The present study shows that caerulein, a member of the cholecystokinin-(CCK) family of gut hormones that also occurs in neural tissue (BEINFELD, 1983), is present in the secretion of the sacciform cells of teleost skin, in addition to the bombesin and serotonin previously detected in some species. Serotonin immunoreactivity also occurs in pulmonary neuroendocrine cells of Polypterus and Protopterus (ZACCONE et al., 1989b, c).

Bombesin is a peptide having multiple functions in mammals; the biological actions of bombesin in fish are the stimulation of gastric acid secretion and rectal muscle contraction in the sharks, and a role in the regulation of feeding behaviour (review, VIGNA and THORNDYKE, 1989). In selachians and in bony fish, bombesin-like peptides have been recognized in the endocrine cells and nerves of the intestinal epithelium (Holmgren and NilsSON, 1983b; El-SAlHy, 1984; TAGLIAFIERRO et al., 1988, 1991; FARALDI et al., 1990). According to VIGNA and THORNDYKE (1989), bombesinlike peptides in lower vertebrates show molecular heterogeneity, with significant differences in structure and function compared with mammalian bombesin. Amphibian bombesin antisera failed to give an immunopositive reaction in the endocrine cells of fish gills (ZACCONE et al., 1992a).

Most of the studies concerning gastrin/CCK peptides in fish have dealt with their distribution in endocrine cells of the gastrointestinal tract. In the codfish Gadus morhua, a caerulein-like peptide was reported as the main component of the population of gut endocrine cells (LARSSON and REHFELD, 1977), while in elasmobranchs and cyclostomes, bioassay and immunohistochemical studies revealed the presence of gastrin/CCK-like peptides and caerulein-immunopositive cells in the intestinal epithelium (VAN NOORDEN and Pearse, 1974; Hansen, 1975). Peptides of the gastrin/ CCK family are not localized solely in the endocrine cells of fish, but have also been reported in neurons in both the peripheral and central nervous systems (Notenboom et al., 1981; Holmgren and Nilsson, 1983a, b; BJENNING and HOLMGREN, 1988). Gastrin, caerulein and related peptides influence gastric acid secretion in some non-mammalian species (JöNSSON, 1989), but the function of caerulein in fish is not known.

Sacciform cells, the object of the present study, are exocrine cells that have varying secretions even within a species (MitTAL et al., 1981; WHITEAR, 1986). They may be toxic (KoDAMA et al., 1985) or contain enzymes (ZACCONE, 1982b) or serotonin and regulatory peptides (ZACCONE et al., 1986, 1988). A previous report (ZACCONE et al., 1987) that bombesin immunoreactivity occurred in some superficial epidermal cells as well as in sacciform cells has not been confirmed, and this appearance may relate to the presence of discharged sacciform cell secretion at the surface of the skin. Sacciform cell secretions may serve as intraspecific alarm signals in some cases (SMITH, 1986; HUGIE et al., 1991).

Serotonin and bombesin have been demonstrated also in the holocrine club cells of some teleosts (ZACCONE et al., 1990 and unpublished observations). In ostariophysan fish, club cells are the production site of an alarm substance (not a peptide) which is responsible for the fright reaction, a defensive behavior against predators (PFEIFFER, 1977, 1982). In the catfish Plotosus lineatus, club cells contain toxins (SHIOMI et 
al., 1988), while in eels they contain hemaglutinin (SUZUKI and KANEKO, 1986). Endogenous lectins were demonstrated in club cells of cypriniform and siluriform fishes by DANGUY et al. (1991), as were chondroitin and keratan sulphate by RALPHS and BENJAMIN (1992). It is probable that the club cells have multiple functions.

The sacciform cells provide a closer parallel to the granular glands of amphibian skin, which produce secretions of a repellant nature, or in some species, highly toxic. In Xenopus laevis, the presence of caerulein was demonstrated by bioassay, chromatography and radioimmunoassay (RIA) (INSELVINI, 1975; DOCKRAY and Hopkins, 1975; DimALINE, 1983; FluCHER et al., 1986), and its coexistence with serotonin in the granular glands by SEKI et al. (1989). Immunohistochemical investigations revealed the presence of various skin peptides and amines in the skin of other amphibian species, for instance BENNETT et al. (1981), YoshIE et al. (1985), see also ERSPAMER et al. (1984, 1986). Thus both amphibian and fish skin secretions can contain large amounts of bioactive peptides and amines similar to mammalian brain-gut peptides (PEARSE, 1976; ERSPAMER, 1983).

Assuming that the primary function of the bioactive amines and peptides is to act as transmitters in neurons and paraneurons, and that the genetic potential to produce them is present in other cell-types, their presence in exocrine glands in two vertebrate groups, not closely connected phylogenetically-i.e. the teleost fish and the amphibians-suggests that these substances can be put to use in deterrent secretions against predators by independent evolution. The target would then be another organism. However, it remains to be demonstrated whether the substances in question are themselves deterrent, or merely combined with other active compounds. In this case bioactive peptides would promote secretion in the sacciform cells as demonstrated for some neuropeptides in exocrine glands (LUNDBERG et al., 1980).

Acknowledgements. Dr. Mary WHITEAR has been most helpful in making useful comments, linguistic corrections and finalization of the manuscript. Grateful thanks are also due to Prof. R. J. F. Smith (Biology Department, University of Saskatchewan, Saskatoon, Canada) for reading the manuscript and for helpful suggestions.

\section{REFERENCES}

Anastasi, A., V. Erspamer and M. Bucci: Isolation and structure of caerulein, a decapeptide from the skin of Hyla caerulea. Experientia 23: 699-700 (1968a).

Anastasi, A., V. Erspamer and R. Endean: Isolation and aminoacid sequence of caerulein, the active decapeptide of the skin of Hyla caerulea. Arch. Biochem. Biophys. 125: 57-68 (1968b).

BEINFELD, M. C.: Cholecystokinin in the central nervous system: a minireview. Neuropeptides 3: 411-427 (1983).

Bennett, G. W., M. Ball, R. H. Clother and C. A. MARSDEN: Location and release of TRH and 5-HT from amphibian skin. Cell. Biol. Int. Rep. 5: 151-158 (1981).

BJEnning, C. and S. Holmgren: Neuropeptides in the fish gut. An immunohistochemical study of evolutionary patterns. Histochemistry 88: 155-163 (1988).

Coons, A. H., E. H. Leduc and J. M. Connelly: Studies on antibody production. I. A method for the histochemical demonstration of specific antibody and its application to a study of hyperimmune rabbit. J. Exp. Med. 102: 49-59 (1955).

Danguy, A., F. Genten and H. J. Gabius: Histochemical evaluation of application of biotinylated neoglycoproteins for the detection endogenous sugar receptors in fish skin. Eur. J. Bas. Appl. Histochem. 35: 341-357 (1991)

Dimaline, R.: Is caerulein amphibian CCK? Peptides 4: 457-462 (1983).

DockraY, G. J. and C. R. Hopkins: Caerulein secretion by dermal glands in Xenopous laevis. J. Cell. Biol. 64: 724-733 (1975).

El-SalHY, M.: Immunocytochemical investigation of the gastroentero-pancreatic (GEP) neurohormonal peptides in the pancreas and gastro-intestinal tract of the dogfish, Squalus acanthias. Histochemistry 80: 193-205 (1984).

ERSPAMER, V.: Amphibian skin peptides in mammals -looking ahead. Trends Neuro. Sci. 6: 200-201 (1983).

Erspamer, V., G. Falconieri Erspamer, G. Mazzanti and R. Endean: Active peptides in the skins of one hundred amphibian species from Australia and Papua, New Guinea. Comp. Biochem. Physiol. 77C: 99-108 (1984).

Erspamer, V., G. Falconieri Erspamer and J. M. Cei: Active peptides in the skin of two hundred and thirty American amphibian species. Comp. Biochem. Physiol. 85C: 125-137 (1986).

Faraldi, G., A. Vallarino, G. Tagliafierro, L. Bor GIANI and T. ZANIN: Enteric nerve fibres in the intestinal mucosa of an elasmobranch. Boll. Zool. 57: 317-323 (1990).

Flucher, B. E., C. Lenglachner-Bachinger, K. PohlhmMER, H. AdaM and C. Mollay: Skin peptides in Xenopus laevis: Morphological requirements for precursor processing in developing and regeneration granular skin gland. J. Cell. Biol. 103: 2299-2309 (1986). 
FuJiTA, T.: Present status of paraneuron concept. Arch. Histol. Cytol. Suppl. 52: 1-8 (1989).

Fujita, T., T. Kanno and S. Kobayashi: The paraneuron. Springer-Verlag, Tokyo, 1988.

HANSEN, D.: Evidence of a gastrin-like substance in Rhinobatus productus. Comp. Biochem. Physiol. 52C: 61-63 (1975).

HolmgRen, S. and S. Nilsson: VIP-, bombesin- and neurotensin-like immunoreactivity in neurons of the gut of the holostean fish, Lepidosteus platyrhincus. Acta Zool. 64: 25-32 (1983a).

: Bombesin-, gastrin/CCK-, 5-hydroxytryptamine-, neurotensin-, somatostatin- and VIP-like immunoreactivity and catecholamine fluorescence in the gut of the elasmobranch, Squalus acanthias. Cell Tiss. Res. 234: 595-618 (1983b).

Hugie, D. M., P. L. Thuringer and R. J. F. Smith: The response of the tidepool sculpin, Oligocottus maculosus, to chemical stimuli from injured conspecifics, alarm signalling in the Cottidae ( Pisces). Ethology 89: 322-334 (1991).

IgUChI, K., C. Yanaihara, M. Kubota, T. Iwanaga, T. Fujita, Y. Matsuo, A. MiYoshi and N. Yanaihara: Porcine cholecystokinin-33 amino-terminal specific radioimmunoassay developed with synthetic porcine cholecystokinin-33 amino-terminal heptacosapeptide. Biomed. Res. Suppl. 4: 189-196 (1983).

INSELVINI, M.: First appearance of caerulein during the development of Xenopus laevis. Gen. Pharmacol. 6:215217 (1975).

Jönsson, A. C.: Gastrin/cholecystokinin-related peptides - comparative aspects. In: (ed. by) S. HoLmGREN: The comprative physiology of regulatory peptides. Chapman and Hall, London-New York, 1989 (p. 61-86).

Kodama, M., S. Sato, T. OGata, Y. Suzuki, T. Kaneko and K. AIDA: Tetrodotoxin secreting glands in the skin of puffer fishes. Toxicon 24: 819-829 (1986).

LARSSON, L. I. and J. F. REHFELD: Evidence for a common evolutionary origin of gastrin and cholecystokinin. Nature (Lond.) 269: 335-338 (1977).

LundBerg, J. M., A. ANGGARD, J. FAHRENKRUg, T. HöKFELT and V. MUTT: Vasoactive intestinal polypeptide in cholinergic neurons of exocrine glands: functional significance of coexisting transmitters for vasodilatation and secretion. Proc. Nat. Acad. USA 77: 1651-1655 (1980).

Mittal, A. J., M. Whitear and A. M. Bullock: Sac ciform cells in the skin of teleost fish. Z. Mikrosk.-Anat. Forsch. 95: 559-585 (1981).

Notenboom, C. D., J. C. Garand, J. Doerr-Schott and M. Terlou: Localization by immunofluorescence of a gastrin-like substance in the brain of the rainbow trout, Salmo gairdneri. Cell Tiss. Res. 214: 247-255 (1981).

Pearse, A. G. E.: Peptides in brain and intestine. Nature (Lond.) 262: 92-94 (1976)

Pfeiffer, W.: The distribution of fright reaction and alarm substance cells in fishes. Copeia 653-665 (1977).

: Chemical signals in communication. In: (ed. by) T. J. HARA: Chemoreception in fishes. Elsevier, Amsterdam, 1982 (p. 306-326).
RAlPhs, J. R. and M. Benjamin: Chondroitin and keratan sulphate in the epidermal club cells of teleosts. J. Fish. Biol. 40: 473-475 (1992).

Renda, T., L. D'Este, A. Fasolo, L. H. Lazarus, F. MinNiti and V. ERSPAMER: Brain-gut-skin peptides: an update overview. Arch. Histol. Cytol. 52, Suppl.: 317323 (1989).

Seki, T., S. KikuYama and N. Yanaihara: Development of Xenopus laevis skin glands producing 5-hydroxytriptamine and caerulein. Cell Tiss. Res. 258: 483-489 (1989).

Shiomi, K., M. TakamiYa, T. KikUChI and Y. SuZUKI: Toxins in the skin secretion of the oriental catfish (Plotosus lineatus): Immunological properties and immunocytochemical identification of producing cells. Toxicon 26: 353-361 (1988).

Smith, R. J. F.: Reaction of Percina nigrofasciata, Ammocrypta beani and Etheostoma swaini (Percidae, Pisces) to conspecific and intergeneric skin extracts. Can. J. Zool. 60: 1067-1072 (1982).

-: The evolution of chemical alarm signals in fishes. In: (ed. by) D. Duvall, D. Muller-Schwarze and R. M. SilversteIN: Chemical signals in vertebrates 4. Plenum Publishing Corporation, New York, 1986 (p. 99 115).

STERnBerger, L. A.: Immunocytochemistry. 2nd ed. John Wiley and Sons, New York, 1979.

SuZuKI, Y. and T. KANEKo: Demonstration of mucous hemagglutinin in the club cells of eel skin. Devel. Comp. Immunol. 10: 509-518 (1986).

Tagliafierro, G., G. Zaccone, E. Bonini, G. Faraldi, L. Farina, S. Fasulo and G. G. Rossi: Bombesin-like immunoreactivity in the gastrointestinal tract of some lower vertebrates. Bombesin-like immunoreactivity in health and desease. Ann. New York Acad. Sci. 547: 458460 (1988).

Tagliafierro, G., G. Zaccone, G. G. Rossi, A. Puccioni, S. Fasulo and L. Farina: Bombesin-like immunoreactivity in the gastro-entero-pancreatic system of Hydromantes italicus Dunn. In: (ed. by) G. GHIARA: Symposium on the evolution of terrestrial vertebrates. Mucchi, Modena, 1991 (p. 603-611).

Van Noorden, S. and A. G. E. Pearse: Immunoreactive polypeptide hormones in the pancreas and gut of the lamprey. Gen. Comp. Endocrinol. 23: 311-324 (1974)

Vigna, S. R. and M. C. Thorndyke: Bombesin. In: (ed. by) S. HolmGREN: The comparative physiology of regulatory peptides. Chapman and Hall, London-New York, 1989 (p. 33-60).

WhiteAR, M.: The skin of fishes including cyclostomes. In: (ed. by) J. Bereiter-Hahn, A. G. Matoltsy and S. RICHARDS: Biology of the integument, Vol. 2, Vertebrates. Springer-Verlag, Berlin-Heidelberg. 1986 (p. 8$38)$.

Yoshie, S., T. Iwanaga and T. Fujita: Coexistence of bombesin and 5-hydroxytryptamine in the cutaneous gland of the frog, Bombina orientalis. Cell Tiss. Res. 239: 25-29 (1985) 
Zaccone, G.: Studies on the structure and histochemistry of the epidermis in the air-breathing teleost Mastacembelus armatus (Mastacembelidae, Pisces). Z. Mikrosk. Anat. Forsch. 95: 809-826 (1981a).

: Histochemical studies of glycoproteins and activities of some enzymes in the skin epidermis and sucking disc of connemara clingfish Lepadogaster candollei Risso 1810 (Gobiesociformes, Pisces). Arch. Biol. (Bruxelles) 92: 317-342 (1981b)

-: Histochemical studies of epithelial mucosubstances, respiratory and pentose shunt enzymes in the skin epidermis of the air-breathing fish Mastacembelus erytrotaenia. Gegenbaurs Morphol. Jahrb. Leipzig 128: 918-921 (1982a)

: Histochemical studies of some hydrolytic and oxidative enzymes in the skin epidermis of the clingfish Lepadogaster candollei Risso (Gobiesociformes, Pisces). Bas. Appl. Histochem. 26: 199-207 (1982b).

-: Neuron-specific enolase and serotonin in the Merkel cells of the conger eel (Conger conger) epidermis. An immunohistochemical study. Histochemistry 85: 29-34 (1986).

Zaccone, G., S. Fasulo, P. Lo Cascio and A. Licata: 5 -hydroxytryptamine immunoreactivity in the epidermal sacciform gland cells of the clingfish Lepadogaster candollei Risso. Cell Tiss. Res. 246: 679-682 (1986).

Zaccone, G., S. Fasulo, P. Lo Cascio, A. Licata and L. AINIS: Occurrence of gastrin-releasing peptide-like and bombesin-like immunoreactivities in the epidermal sacciform gland cells of the clingfish Lepadogaster candollei. Bas. Appl. Histochem. 31: 455-464 (1987).

Zaccone, G., S. Fasulo, A. Licata, L. Ainis and P. Lo CASCIO: GRP/Bombesin immunoreactive sacciform gland cells in the epidermis of the clingfish, Lepadogaster candollei. Bombesin-like peptides in health and disease. Ann. New York Acad. Sci. 547: 464-465 (1988).
Zaccone, G., L. Ainis, S. Fasulo, P. Lo Cascio, A. MAUCERI and A. LICATA: Merkel cells detected by immunocytochemistry in the epidermis of the freshwater catfish Heteropneustes fossilis (Bloch). Zool. Jahrb. Anat. 119: 129-134 (1989a).

Zaccone, G., G. Tagliafierro, L. G.-Witalinska, S. Fasulo, L. Ainis and A. Mauceri: Serotonin-like immunoreactive cells in the pulmonary epithelium of ancient fish species. Histochemistry 92: 61-63 (1989b).

Zaccone, G., L. G.-Witalinska, J. M. LauWeryns, S. Fasulo and G. Tagliafierro: Fine structure and serotonin immunohistochemistry of the neuroendocrine cells in the lungs of the bichirs Polypterus delhezi and $P$. ornatipinnis. Bas. Appl. Histochem. 33: 277-287 (1989c).

Zaccone, G., G. Tagliafierro, S. Fasulo, A. Contini, L. AINIS and M. B. RICCA: Serotonin-like immunoreactivity in the epidermal club cells of teleost fishes. Histochemistry 93: 355-357 (1990).

Zaccone, G., J. M. Lauweryns, S. Fasulo, G. TagliafiERRO, L. AINIS and A. LiCATA: Immunocytochemical localization of serotonin and neuropeptides in the neuroendocrine paraneurons of teleost and lungfish gills. Acta Zool. 73: 177-183 (1992a).

Zaccone, G., S. E. Wendelar Bonga, G. Flik, S. Fasulo, A. Licata, P. Lo Cascio, A. Mauceri and E. R. LAURIAN0: Localization of calbindin D28K in fish gill: a light microscopic and immunoelectron histochemical study. Regul. Pept. 41: 195-208 (1992b).

Profs. Salvatore FASULO and Giacomo ZACCONE Department of Animal Biology and Marine Ecology Faculty of Science, University of Messina $\mathrm{C} / \mathrm{da}$ Sperone 31.

I-98166 S. Agata (Messina), Italy 